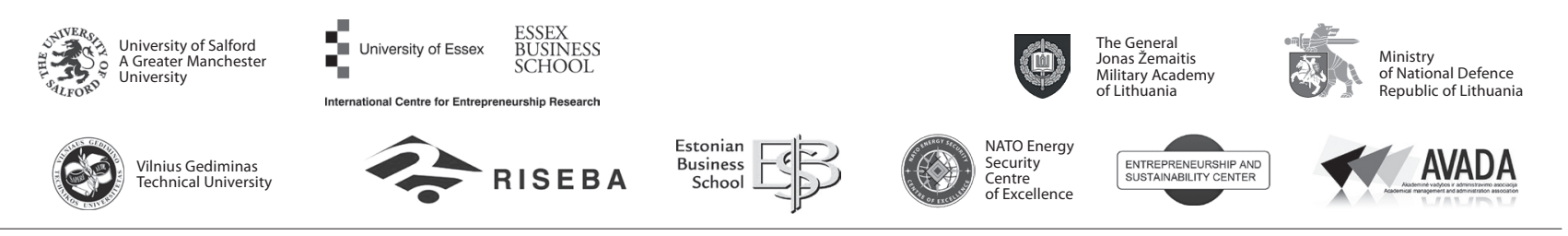

\author{
JOURNAL OF SECURITY AND SUSTAINABILITY ISSUES \\ ISSN 2029-7017 print/ISSN 2029-7025 online \\ 2018 March Volume 7 Number 3 \\ http://doi.org/10.9770/jssi.2018.7.3(14)
}

\title{
SAVINGS AND CREDIT COOPERATIVES IN PICHINCHA, ECUADOR: IS THIS A SUSTAINABLE SOCIAL MANAGEMENT CASE?
}

\author{
Angie Fernández ${ }^{1}$, Alain Hernández², Marco Hernández ${ }^{3}$, Oscar Chicaiza ${ }^{4}$ \\ ${ }^{1,3,4}$ Department of Trade, Administrative and Economics Sciences, \\ Universidad de las Fuerzas Armadas ESPE, Ecuador \\ ${ }^{2}$ Postgraduate Program in Regional Development and Agribusiness \\ Universidad Estadual del Oeste de Paraná (UNIOESTE), Brasil
}

E-mail: ${ }^{1}$ aafernandez2@espe.edu.ec, ${ }^{2}$ santoyocuba@gmail.com, ${ }^{3}$ mahernandez@espe.edu.ec, ${ }^{4}$ olchicaiza@espe.edu.ec

Received 20 March 2017; accepted 10 January 2018

\begin{abstract}
Cooperatives have the potential to develop an economic, social and environmental activity in a sustainable manner. In particular, social management is aimed at meeting the needs of its partners, families and community in an efficient and effective way. A study of social management was carried out in 60 savings and credit cooperatives in Pichincha, Ecuador, to determine if this is carried out under sustainability principles, with the determination that the recognition of social responsibility and the integral management of the economic and social issues, depends on the segment to which they belong, in which the non-definition of the social budget has a negative influence. The ignorance of the partners about the principles of Cooperativism; the inexistence of Cooperative Education Committees, specifically environmental education and action programs; the lack of granting credits for partner undertakings and the non-application of the cooperative social balance sheet are also other issues that damage the correct functioning of these associative forms. There were recognized areas to be strengthened to guarantee the sustainability of cooperatives as an associative form, such as the definition of social objectives; the active participation of the partners in decision-making and of another two interest groups (families and community).
\end{abstract}

Keywords: cooperatives, social management, sustainability, Ecuador

Reference to this paper should be made as follows: Fernández, A.; Hernández, A.; Marco Hernández, M.; Chicaiza. O. 2018. Savings and credit cooperatives in Pichincha, Ecuador: is this a sustainable social management case?, Journal of Security and Sustainability Issues 7(3): 549-558. http://doi.org/10.9770/jssi.2018.7.3(14)

JEL Classifications: M14, M19

\section{Introduction}

The management of cooperatives has traditionally been directed towards the economic, financial and/ or productive issues, without assessing in all cases the need for the social component to be correctly configured in the administrative model (Fernández and Rivera, 2016). This implies developing a process of planning, organizing, executing and controlling social activities aimed at raising the quality of life of partners, other workers, their families and community, in a sustainable manner (Alfonso and Rivera, 2013; Jankalová, Jankal, 2017), as it is done with the rest of the business functions.

According to Garrido et al. (2017) the type of management model to be chosen in the cooperatives depends on three fundamental factors: the size, age and activity of the cooperative; which must always respect the principle of democratic management. These authors acknowledge that, according to previous studies, the dualist model 
(professionalized management) is the one that predominates in credit cooperatives. On the other hand, Gallardo et al. (2015) show the possibility of developing a model of social responsibility in cooperatives, similar to a traditional company, with advantages in the cooperative given its associative and social nature. Under this approach, the social balance is recognized as a tool for the cooperative company to communicate its social results to its stakeholders, especially related to compliance with cooperative principles (Acosta \& Levin, 2015).

In the aspiration of measuring the social action of the cooperative it is necessary to rethink the traditional concepts of "efficiency and effectiveness", which must be adapted to the aspirations of success and sustainability of the cooperatives (Labrador \& Rivera, 2016), designing adequate indicators that guarantee a systemic evaluation of the social function of this type of entity.

In general, it is recognized by different authors, the need for cooperatives to develop their own model of social management - in balance with the rest of business activities-; able to guarantee, in a sustained and sustainable manner, the needs of its main interest groups: partners, families, other workers, community and society; while applying the sustainability approach directed to the change "in which the exploitation of the resources, the direction of the investments, the direction of the technological development and the institutional change are in complete harmony and enhance the current and future possibilities to solve the needs of the human being “(WCED, 1987).

The essence of cooperative as an economic and social enterprise makes it a theoretically "sustainable" source, since at its foundations it contains the balance between the generation and use of material, financial and human resources with the primary objective of satisfying the needs of its main interest groups, and not the simple interest of profit, based on universally recognized principles and values (Pérez \& Pérez, 2016). The current context for the development of the cooperative under a sustainable development model is framed by the Social and Solidarity Economy as an emerging economic model that prioritizes the human being and the environment, against capital (Vázquez, 2016), with advantages over other types of organizations (ILO/ICA, 2015). However, experiences at the international level show that not all cases exploit the potential of cooperatives to achieve standards of efficiency and economic and social effectiveness, which sometimes endangers even the sustainability of the various forms of association (Rodríguez \& Ramírez, 2016).

The cooperative sector in Ecuador is mainly directed to the financial and non-financial sectors (transport, production, housing, consumption and services) under the principles of organization and development of various processes that meet the needs and generate incomes, based on solidarity, cooperation and reciprocity, privileging the human being and his work, in harmony with nature (Ecuador, 2011, p.3). In the country, financial cooperatives are classified into five segments depending on the volume of financial assets. In particular, sectors four and five, on which the present study focuses, represent cooperatives with a lower volume of assets (less than five million dollars), and which have traditionally been less analyzed due to their size (Galarza et al., 2017).

According to the Organic Law of the Popular and Solidarity Economy (Ecuador, 2011, p.37), the statute of financial cooperatives must be drawn up "under criteria of security, liquidity and sustainability"; to which, if Gallopín (2003, p.37) considers that "sustainability is an attribute of systems open to interactions with its external world ... the dynamic preservation of the identity of the system in the midst of permanent changes ... Sustainable development is a process of directional change, through which the system improves in a sustainable way over time ", which implies that the cooperative from the economic / financial; social and environmental point of view, must guarantee sustained and sustainable development. Previous studies have focused basically on the analysis of the financial sustainability of this type of entities based on three axes: institutional and financial sustainability of services (Morales, 2014).

Under the approach proposed by Gallopín addressed to the analysis of process / system, relationship with the environment and permanent change that will guarantee the sustainability of the associative cooperative form, the objective of the research is to analyze the social management of the savings and credit cooperatives of the segments four and five of Pichincha, Ecuador. 


\section{Methodology}

To develop the investigative process, theoretical and empirical methods were used. From the empirical point of view, scientific observation was carried out through a survey on social management, adapted from previous studies (Fernández, 2011), to savings and credit cooperatives characteristics.

Table 1 shows the data of active credit and savings cooperatives in the province of Pichincha in 2016, in segments four and five.

Table 1. Active savings and credit cooperatives of segments four and five in Pichincha, Ecuador

\begin{tabular}{|c|c|}
\hline Segment & Number of cooperatives \\
\hline 4 & 54 \\
\hline 5 & 111 \\
\hline Total & 165 \\
\hline
\end{tabular}

Source: Prepared by the authors from Superintendence of Popular and Solidarity Economy (2016)

For the calculation of the sample size, the formula of the simple estimation method for the Random Unrestricted Sampling was applied (Calero, 2003). The defined parameters were: population $(\mathrm{N}=165)$; level of significance $(\alpha=0.05)$; absolute error $(\mathrm{d}=0.10)$; probability value $(\mathrm{P}=0.5)$. The sample size calculated is 60 cooperatives. For the determination of the number of cooperatives per segment, the formula for calculating the sample was applied by strata with proportional allocation (Calero, 2003). Table 2 shows the allocation by strata of cooperatives to be studied.

Table 2. Assignment of cooperatives to study by strata

\begin{tabular}{|c|c|c|}
\hline Segment & $\mathbf{N}_{\mathbf{h}}$ & $\mathbf{n}_{\mathbf{h}}$ \\
\hline 4 & 54 & 19 \\
\hline 5 & 111 & 41 \\
\hline
\end{tabular}

Source: Prepared by the authors

The selection of the 19 cooperatives of segment four and the 41 cooperatives of segment five that guarantee the randomness in the study, was carried out using the Table of Random Numbers of Kendall \& Babington (1939).

In the study, 96 variables were evaluated, concentrating the analysis in the 20 most important according to the weight in the sustainable development of social management, in order to describe, verify and / or compare their behavior, dependence, association and possible correlation, taking into consideration the segment to which the cooperatives belong. The data analysis was performed with SPSS v23 and STATA v15.

\section{Empirical results and discussion}

A Chi-square independence test was carried out, in its contingency table mode, to verify possible dependency relationships between each of the variables studied and the segment to which they belong. The results obtained showed, with a reliability of $95 \%$, that there is a significant relationship of dependence between the integral management of economic and social activities in the cooperative and the identification of their social responsibility, according to the type of segment. 
Table 3. Chi-square independence test, contingency table modality

\begin{tabular}{|c|c|c|c|c|c|}
\hline \multirow{3}{*}{$\begin{array}{l}\text { Variable } \\
\text { Is the economic and social activities integrally managed in the cooperative? }\end{array}$} & \multicolumn{5}{|c|}{ Chi-square Tests } \\
\hline & \multirow{2}{*}{$\begin{array}{l}\text { Value } \\
7,691\end{array}$} & \multirow{2}{*}{$\begin{array}{c}\begin{array}{c}\text { Correction for } \\
\text { continuity }\end{array} \\
5,936\end{array}$} & \multirow{2}{*}{$\begin{array}{c}\text { gl } \\
1\end{array}$} & \multicolumn{2}{|c|}{$\begin{array}{c}\text { Sig. Asymptotic } \\
\text { (bilateral) }\end{array}$} \\
\hline & & & & 0,006 & 0,015 \\
\hline Does the cooperative have its social responsibility identified? & 8,958 & 7,261 & 1 & 0,003 & 0,007 \\
\hline $\begin{array}{l}\text { Are the social objectives contemplated as part of the cooperative's strategic } \\
\text { plan and annual operational plans? }\end{array}$ & 1,567 & 0,712 & 1 & 0,211 & 0,399 \\
\hline Is there a budget for social management in the cooperative? & 0,368 & 0,095 & 1 & 0,544 & 0,758 \\
\hline The principles of Cooperativism are known by & 4,298 & - & 3 & 0,231 & - \\
\hline Is the social balance executed in the cooperative? & 0,693 & 0,308 & 1 & 0,405 & 0,579 \\
\hline
\end{tabular}

Source: Prepared by the authors from statistical processing results

The two variables mentioned above are those that synthesize the meaning of the social activity of the cooperatives studied, in relation to the management model they develop in a sustainable manner. As shown in Figure 1, the cooperatives in segment five, that is, those that manage assets up to one million dollars, present the greatest difficulties, which means that the social activity cannot be carried out in a harmonious manner with the financial function. In the opinion of Gallardo \& Castilla (2015), the relationship between the social and economic function in cooperatives is essential, by implementing their social responsibility in an integral way (Jankalová \& Jankal, 2017), which should be observed even by other types of companies as an example of a sustainability model. In relation to the recognition of social responsibility, as shown in Figure 2, the situation is similar, with segment five having the greatest deficiencies in this variable.

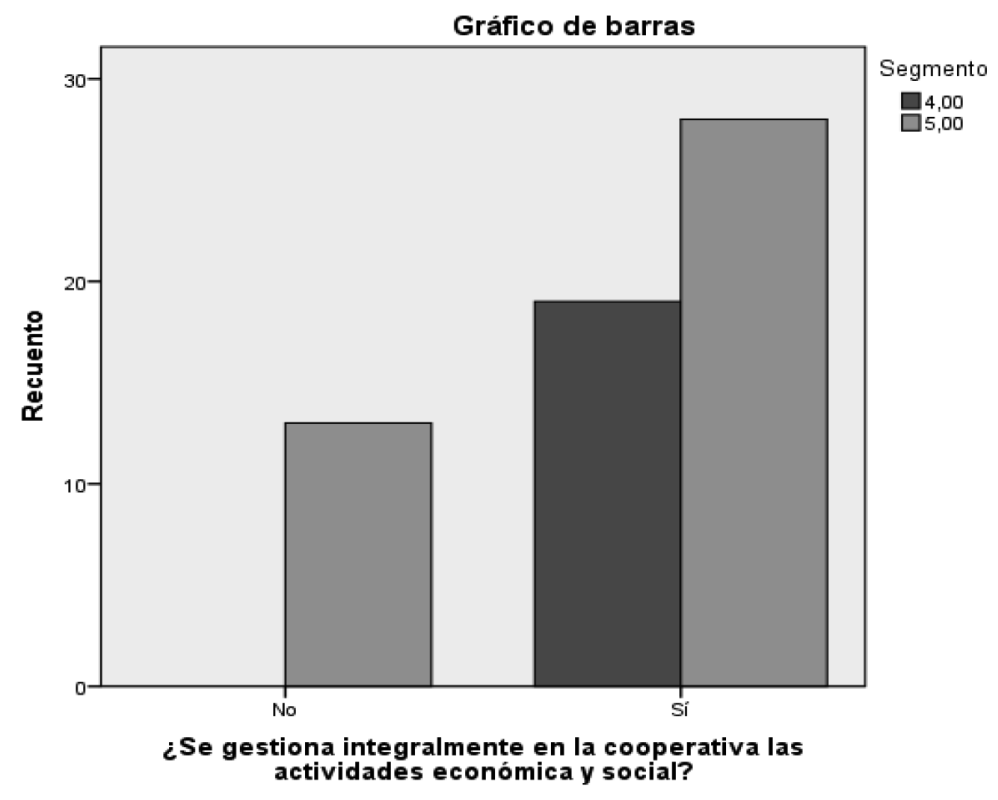

Figure 1. Graph of the variable "Integral management in the cooperative of economic and social activities"

Source: Statistical processing results 


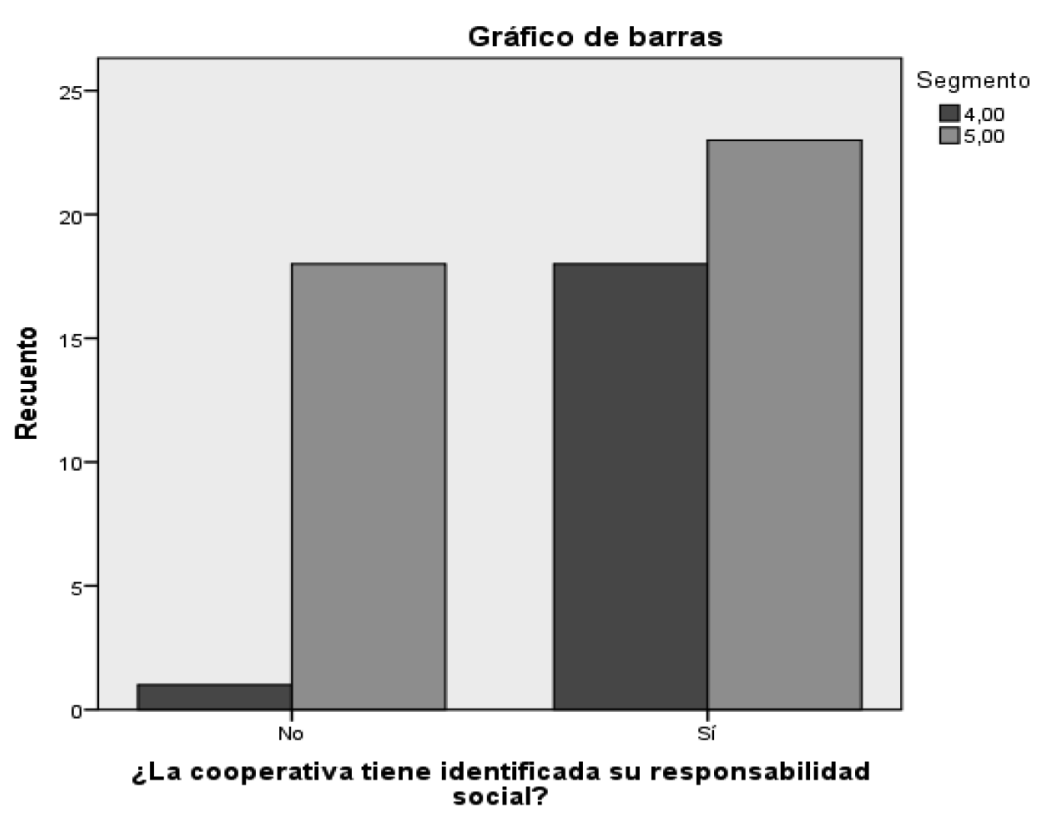

Figure 2. Graph of the variable "Identification of the social responsibility"

Source: Statistical processing results

It was determined in turn, by calculating symmetric measures to determine the intensity or strength of said possible dependency relationships, such as: Coefficient of contingency $(C)$, Coefficient Phi $(\phi)$ and Coefficient of Cramer (V), which variables with higher coefficients were: the integral management of the economic and social activities in the cooperative and the identification of their social responsibility, which although they do not correspond to high values, they demonstrate the strength of this relationship, above the rest, in a meaningful way.

Table 4. Symmetric measures associated with the Chi-square independence test, modality of contingency tables for categorical (nominal) variables

\begin{tabular}{|l|c|c|c|}
\hline \multicolumn{1}{|c|}{ Variable } & \multicolumn{2}{c|}{ Nominal } \\
\cline { 2 - 4 } & $\begin{array}{c}\text { Coefficient of } \\
\text { contingency }(\mathrm{C})\end{array}$ & $\begin{array}{c}\text { Coefficient Phi } \\
(\phi)\end{array}$ & $\begin{array}{c}\text { Coefficient of } \\
\text { Cramer }(\mathrm{V})\end{array}$ \\
\hline Is the economic and social activities managed integrally in the cooperative? & 0,337 & $-0,358$ & 0,358 \\
\hline Does the cooperative have its social responsibility identified? & 0,360 & $-0,386$ & 0,386 \\
\hline
\end{tabular}

Source: Prepared by the authors from statistical processing results

The comparison test of proportions for independent samples in dichotomous variables $(\alpha=0.05)$, allowed to determine if there were significant differences in the perceptions of the respondents in each of the questions according to the segment, ratifying the same variables with significant differences (Table 5).

Table 5. Proportion comparison test for independent samples

\begin{tabular}{|c|c|c|c|c|c|c|c|}
\hline \multirow{3}{*}{$\begin{array}{l}\text { Variable } \\
\text { Is the economic and social activities } \\
\text { managed integrally in the cooperative? }\end{array}$} & \multicolumn{2}{|c|}{$\begin{array}{c}\text { Segment } 4 \\
\mathrm{n}=19\end{array}$} & \multicolumn{2}{|c|}{$\begin{array}{c}\text { Segment } 5 \\
\mathrm{n}=41\end{array}$} & \multirow{2}{*}{\multicolumn{3}{|c|}{$\mathrm{p}$-level $\left(\mathrm{p}_{\mathrm{a} 4}-\mathrm{p}_{\mathrm{a} 5}\right)$}} \\
\hline & $\mathrm{p}_{\mathrm{a}}$ & $\mathrm{p}_{\mathrm{b}}$ & $\mathrm{p}_{\mathrm{a}}$ & $\mathrm{p}_{\mathrm{b}}$ & & & \\
\hline & 1.0000 & 0.0000 & 0.6829 & 0.3161 & 0.9972 & $0.0055^{*}$ & $0.0028^{*}$ \\
\hline $\begin{array}{l}\text { Does the cooperative have its social } \\
\text { responsibility identified? }\end{array}$ & 0.9474 & 0.0526 & 0.5610 & 0.4390 & 0.9986 & $0.0028^{*}$ & $0.0014 *$ \\
\hline
\end{tabular}


The sustainability of the social management model - balanced with the financial and economic function - of the credit and savings cooperatives will depend, among other factors, on their planning and social budgeting, which sets the social objectives and the resources needed to its fulfillment; the structures, processes, functions and responsibilities for the fulfillment of said objectives are established; the duality of the partner as decision maker and manager is encouraged, motivating and achieving the democratic participation of these, recognizing the corporate culture as a whole, which does not separate the corporate from the business; as well as that, a control activity is carried out through balance and social audit tools (Fernández, 2011). In relation to this, in the research it was determined that the definition of social objectives is carried out in $87 \%$ of the cooperatives, while only $68 \%$ have a social budget; in both cases regardless of the segment to which the cooperatives belong, according to the results of the Chi-square independence test (Table 3 ).

The knowledge of the principles of Cooperativism is a premise for the partners of this type of companies to know the particularities of the management model and to develop an active activity in decision-making (García et al., 2017) within the framework of a system of participatory management (Acuña et al., 2003). Figure 3 shows the descriptive behavior of the variable "Knowledge of the principles of Cooperativism", in which it is evident that not all the members of the cooperatives studied have knowledge of them, which according to the Chi-square independence test (Table 3), it is independent of the segment to which the entities belong. In the above, it is important that only $46 \%$ of the cooperatives have an Education Committee, establishing a positive relationship between both variables according to Pearson's R Coefficient (Table 6).

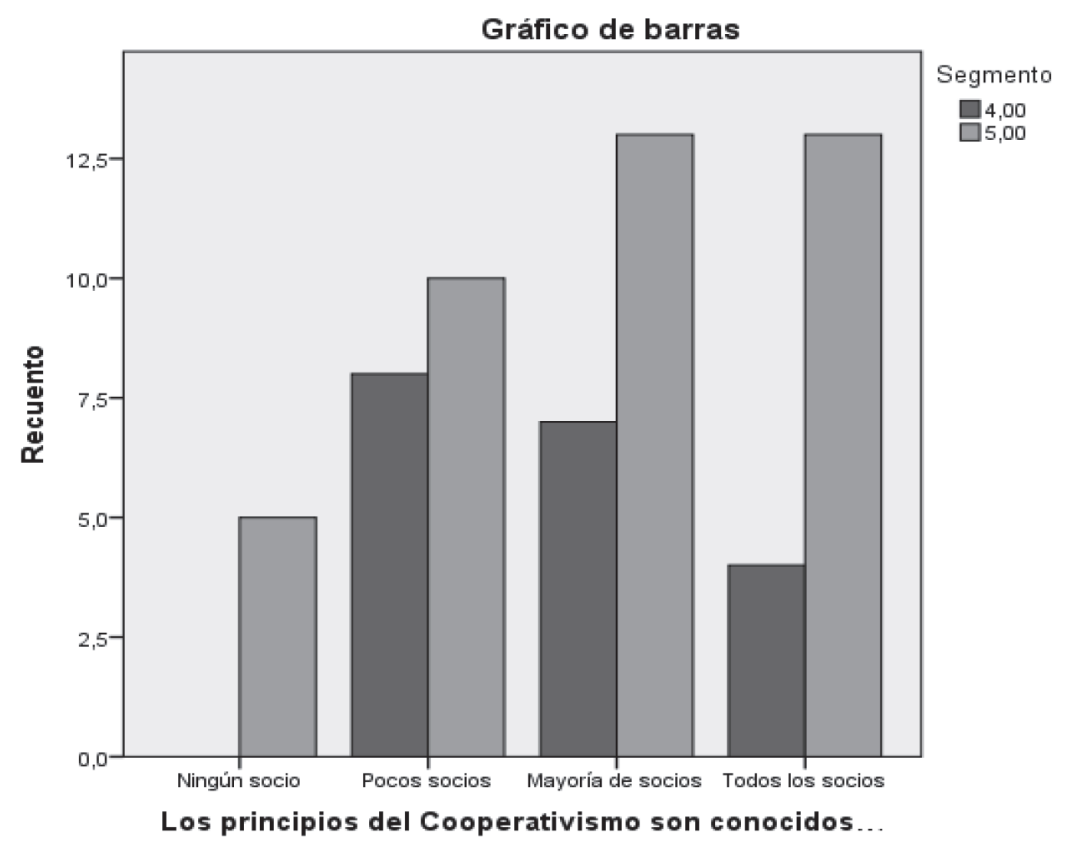

Figure 3. Graphic of the variable "The principles of Cooperativism are known by *"

Source: Statistical processing results 
Table 6. Pearson's R coefficient

\begin{tabular}{|l|c|}
\hline \multicolumn{1}{|c|}{ Related variables } & Pearson R \\
\hline Knowledge of the principles of Cooperativism and existence of a Cooperative Education Committee & 0,21804621 \\
\hline $\begin{array}{l}\text { Participation of the partners in the process of defining and approving the social budget and the existence of a } \\
\text { Cooperative Education Committee }\end{array}$ & $-0,14239383$ \\
\hline Incorporation of the gender approach and existence of a Committee on Cooperative Education & 0,02343163 \\
\hline Attention to the needs of families and increase the sense of belonging of the members & 0,264276 \\
\hline Identification of social responsibility and diversity of services to the community & 0,151293 \\
\hline Identification of vulnerable groups and diversity of services to the community & 0,2955227 \\
\hline $\begin{array}{l}\text { Implementation of education and environmental action programs and quality of the system of registration, evaluation } \\
\text { and measurement of social action }\end{array}$ & 0,07939791 \\
\hline Execution of the social balance and level of communication of the social actions developed by the cooperative & 0,40133879 \\
\hline $\begin{array}{l}\text { Existence of special credit systems for the enterprises and the level of participation of the partners in the preparation } \\
\text { and approval of the strategic plan and operational annual plans of the cooperative }\end{array}$ & 0,16851814 \\
\hline
\end{tabular}

Source: Prepared by the authors from statistical processing results

Note: Low values, both positive and negative, denote the potential to reinforce these relationships between variables

As expressed by Mirabal et al. (2014), cooperative education contributes to the formation of partners, managers and employees in the implementation of the development of the social management model. However, as shown in Table 6, the existence of a Cooperative Education Committee reflects a negative relationship with the level of participation of the partners in the process of defining and approving the social budget in the cooperatives studied. On the other hand, the cooperative education function has managed to influence, albeit slightly, the incorporation of the gender approach in these cooperatives, which is considered one of the elements that can be enhanced in this type of entities due to its characteristics organizational and operational features (Esteban, et al., 2016).

The Rho coefficient of Spearman was applied for the three numerical variables of the study (Table 7), determining that among the three there are significant correlations, among which the highest was manifested between the level of participation of the partners, other workers, families and community in the cooperative education activities that are carried out with the role of the family of the partners in the increase of the sense of belonging to the cooperative.

Table 7. Bivariate correlations from Spearman's Rho coefficient

\begin{tabular}{lll}
\hline Variable & & \\
\hline $\begin{array}{l}\text { Level of participation of the partners in the preparation and approval of the strategic plan and annual } \\
\text { operational plans of the cooperative }\end{array}$ & 1,000 \\
$\begin{array}{l}\text { Level of participation of partners, other workers, families and community in the cooperative education } \\
\text { activities that are carried out }\end{array}$ &, $294^{*}$ & 1,000 \\
Role of the family of the partners in increasing the sense of belonging to the cooperative & $, 355^{* *}, 610^{* *} \quad 1,000$ \\
\hline
\end{tabular}

Source: Prepared by the authors from statistical processing results

The families of the members in the cooperatives constitute an important interest group (Fernández et al., 2017), which has traditionally been studied under the focus of the beneficiary group of the economic and social activity of these organizations (Campos \& Macías, 2017); a change in the directionality of this analysis is determined in the research, if we take into account that the family affects the most effective management of the organization, through the active participation of the partners (see calculation result of Pearson's R Coefficient in Table 6).

Another of the fundamental interest groups for the cooperative is the community with which it is related, demonstrating in the research that the identification of social responsibility and vulnerable groups in the community has a positive correlation with the diversity of services offered by the cooperative, as evidenced in the results 
of Table 6. According to Martínez (2016), the cooperative's relations with the community will guarantee the future, to modify its economic, social and cultural relations in a sustainable manner. Related to the environmental aspect, only $21 \%$ of the cooperatives studied develop environmental education and action programs, slightly related in a positive way to the quality of the system of registration, evaluation and measurement of the social action carried out by the cooperative ( $\mathrm{R}=0,07939791$, in Table 6), becoming one of the aspects that limits the most the sustainable social action of the savings and credit cooperatives by avoiding the environmental component in their activity.

And it is precisely the measurement phase of management indicators, as part of the control, one of the most important for the cooperative (Gongora, et al., 2017); which should be characterized by assuming, in addition to the traditional financial and economic indicators (Tamulevičienè, 2016), social and environmental indicators that guarantee the integral valuation of the business activity. As shown in Figure 4, only $50 \%$ of the cooperatives develop the social balance, regardless of the segment to which they belong according to the Chi-square test (Table 3). However, it was shown that the execution of the social balance has a positive effect on the level of communication of the social actions developed by the cooperative $(\mathrm{R}=0.40133879$, in Table 6$)$. The above ratifies what was expressed by Cajas et al. (2016) in relation to the fact that the social balance is a useful tool for social organizations in the financial sector, by linking social and environmental indicators for their assessment and communication to the internal and external public.

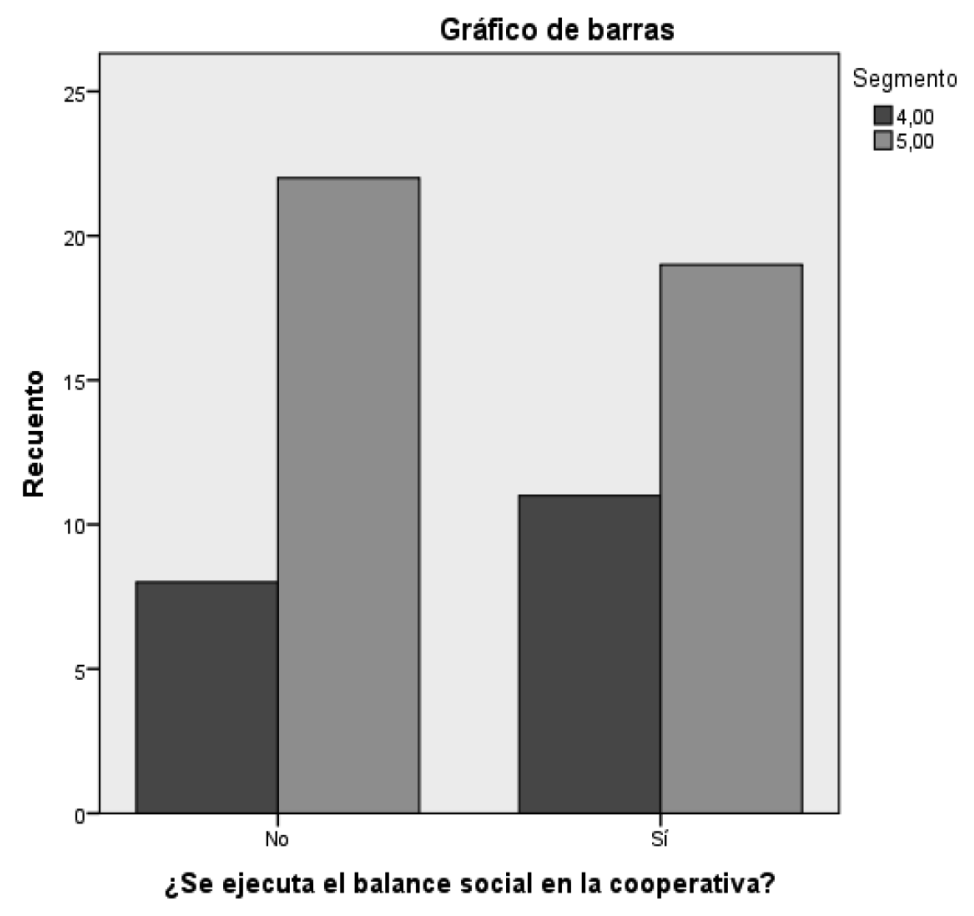

Figure 4. Graph of the variable "Execution of the social balance in the cooperative"

Source: Statistical processing results

One of the most attractive activities that can be developed by savings cooperatives is to offer special credit systems for partners' ventures, which occurs only in 53\% of the cases studied, evidencing that this is positively influenced by the level of participation of the partners in the preparation and approval of the strategic plan and annual operating plans (see results Table 6). 


\section{Conclusion}

In savings and credit cooperatives of segments four and five of Pichincha, Ecuador studied, it was evident that the recognition of social responsibility and the integral management of the economic and social, is dependent on the segment to which they belong, being this the basis for the development of a sustainable model.

The different statistical tests carried out allowed determining that the main aspects that negatively affect the sustainability of the social management system of said cooperatives are: the non-definition of the social budget; the ignorance of the partners of the principles of Cooperativism; the inexistence of Cooperative Education Committees, specifically environmental education and action programs; not granting credits for partner undertakings and the non-application of the cooperative social balance sheet.

In turn, it was shown that these cooperatives can enhance aspects such as the definition of social objectives; the active participation of the partners in decision-making and of other two interest groups (families and community), in their social management model, which will help to guarantee their sustainability as an associative form.

\section{ACKNOWLEDGEMENT}

The work was carried out as part of the research project "Administrative and social management. Case study: Savings and Credit Cooperatives in Pichincha province", of Universidad de las Fuerzas Armadas ESPE, Ecuador.

\section{References}

Acosta, M.C. \& Levin, A. (2015). Panorama on the cooperative social balance in Argentina: implementation modalities. IX RULESCOOP Congress. http://sedici.unlp.edu.ar/bitstream/handle/10915/49843/Documento_completo_.pdf?sequence=1,1-17

Acuña, E., Núñez, A. \& Radrigán, M. (2003). A conceptual framework for the study of participation. UNIRCOOP, 1 (1), $70-84$.

Alfonso, JL. \& Rivera, CA. (2013). Improvement of the Social Management Model in cooperative companies in the province of Pinar del Río. Results and Impacts. Advances, 15(1), 40-53.

Cajas, F.A., Oña, A. \& Pantoja, O. (2016). Social indicators in financial institutions of the popular and solidarity economy. Challenges Journal of Administration Sciences and Economics, 6(12), 133-147.

Calero, A. (2003). Statistics III. Havana, Félix Varela Editorial, 61, 68.

Campos, E. \& Macías, J.A. (2017). Contribution of the transport cooperatives to the development of the Popular and Solidarity Economy in the province of Manabi during the year 2016. Universidad de Especialidades Espíritu Santo: master's thesis, 1-31.

Ecuador (2011). Organic Law of the Popular and Solidarity Economy. Recovered from http://www.seps.gob.ec/documents/20181/25522/ Ley\%20Orga \%C\%\%81 nica\%20E\%20Economy\%\%\%\%\%20Popular\%20and\%20Solidaria.pdf/0836bc47-bf63-4aa0-b945b94479a84ca1,1-4

Esteban, M.L., Gargallo, A.F. \& Pérez, F.J. (2016). Do the cooperatives present favorable contexts for gender equality?: Special reference to the province of Teruel. CIRIEC-Spain, Journal of Public, Social and Cooperative Economics, 88, 61-92.

Fernández, A. (2011). Methodology for the improvement of the Business Management System of the Tobacco Farming Cooperatives of the Pinar del Rio province, Cuba. Universidad de Pinar del Río: doctoral thesis, 1-314.

Fernández, A. \& Rivera, C.A. (2016). Methodology for the improvement of business management in agricultural cooperatives. Ecuador, Universidad de las Fuerzas Armadas ESPE. http://repositorio.espe.edu.ec/bitstream/21000/11693/1/Metodologi\%C2\%B4a\%20para\%20 el\%20perfeccionamiento $\% 20 \mathrm{de} \% 201 \mathrm{a} \% 20$ gestio $\% \mathrm{C} 2 \% \mathrm{~B} 4 \mathrm{n} \% 20$ empresarial $\% 20 \mathrm{en} \% 20$ cooperativas $\% 20$ agropecuarias $\% 20 \% 20$.pdf

Fernández, A., Arias, D.E., Padilla, C., Calero, S. \& Parra, H.A. (2017). Alliances and conflicts between stakeholders in a military hospital: application of the Mactor method. Cuban Journal of Biomedical Research, 36(1), 1-12.

Galarza, S.P, García, J.C., Ballesteros, L., Cuenca, V.E. \& Fernández A. (2017). Organizational structure and leadership styles in Cooperativas de Ahorro y Credito de Pichincha. COODES, 5(1), 19-31. 
Gallardo, D.\& Castilla, F. (2015). Management model for social responsibility in cooperatives. Industrial Economics Magazine, $398,140$.

Gallardo, D., Sánchez, M.I. \& Castilla, F. (2015). Theoretical and methodological framework for the qualitative validation of an explanatory model of Social Responsibility in cooperative societies. Cooperatives Studies Review, 118, 86-121.

Gallopín, G. (2003). Sustainability and Sustainable development: a systemic approach. Chile, ECLAC, 37.

Garcia, G.E., Sánchez, V.E.; Elizalde, D.E \& Fernández, A. (2017). The social management of Savings and Credit Cooperatives in Ecuador. COODES, 5(1), 47-59.

Garrido, I., Salazar, I. \& Vargas, P. (2017). Governance model in Spanish cooperatives. Cooperatives Studies Review, 123, 1-20.

Gongora, H., Rodríguez, P. \& Zumárraga, E. (2017). Importance of the Social Balance in Cooperatives in Ecuador. CienciAmérica Magazine, 6(2), 1-8.

ILO/ICA (2015). Cooperatives and the Sustainable Development Goals. Recovered form: http://www.ilo.org/wcmsp5/groups/public/ ed_emp/emp_ent/coop/documents/publication/wcms_307228.pdf, 1-24.

Jankalová, M.; Jankal, R. (2017). The assessment of corporate social responsibility: approaches analysis. Entrepreneurship and Sustainability Issues, 4(4), 441-459. https://doi.org/10.9770/jesi.2017.4.4(4)

Kendall, M. \& Babington, B. (1939). Randomness and random Sampling numbers. Journal of the Royal Statistical Society, $101,147-166$.

Labrador, O. \& Rivera, C.A. (2016). The socioeconomic efficiency and effectiveness of the management of non-agricultural Cooperatives in Cuba. COODES, 4(2), 149-158.

Martínez, L. (2016). Peasant territories and agrarian reform: the case of the indigenous cooperatives of the Ecuadorian highlands. Agrarian World, 17(35), 1-17.

Mirabal, Y., Marín, I. \& Alfonso, J.L. (2014). Cooperative Education and Management Model of Cooperative Social Responsibility. Advances, 16(1), 9-17.

Morales, C. (2014). Analysis of financial sustainability of the savings and credit cooperatives of Ecuador, period 2005-2011. Pontifical Catholic University of Ecuador, Quito. Recovered from: https:/www.puce.edu.ec/economia/docs/2014/semana-economia/ECONOMIASEMIII-Carina-Morales.pdf, 1- 21.

Pérez, M.O. \& Pérez, G. (2016). Non-Agricultural Cooperatives in the Historical Center of Old Havana: Sustainability and Cooperation. Horizons and Roots, 4(2), 31-38.

Rodríguez, H. \& Ramírez, C.J. (2016). Sustainability analysis of the strengthening processes of a rural association: Asomora a case study. Journal of Agricultural Sciences, 33(1), 9-21.

Tamulevičienė, D. (2016). Methodology of complex analysis of companies' profitability. Journal of Security and Sustainability, 4(1), 53-63.

Vázquez, M. (2016). The Cooperative Societies, an expression of Social Solidarity Economy. The case of the Erandi handicraft producers' cooperative. Economy and Society, January-June, 17-37.

WCED (1987). Our Common Future. Recovered from http://www.un-documents.net/our-common-future.pdf, 1-300. 